\title{
CZYNNIKI SPRZYJAJĄCE PRZEDSIĘBIORCZOŚCI KOBIET W BIZNESIE
}

\author{
Katarzyna Olejniczak \\ Politechnika Częstochowska \\ Wydział Zarządzania
}

\begin{abstract}
Streszczenie: W ostatnim czasie zauważyć można rosnącą rolę kobiet w kreowaniu przedsiębiorczości. Z tego też względu coraz częściej dostrzega się znaczenie polityki różnorodności odnoszącej się do kwestii kobiet na stanowiskach kierowniczych, a przede wszystkim kreujących postawy przedsiębiorcze. Niestety w dalszym ciągu kobiety w nierównym stopniu uczestniczą w zarządzaniu przedsiębiorstwami, podejmowaniu decyzji czy też w realizacji celów organizacji. Wynika to $\mathrm{z}$ faktu, iż to właśnie kobietom stawiane są wyższe wymagania (kwalifikacyjne, organizatorskie, zarządcze) niż mężczyznom. W takim odniesieniu zasadne jest podjęcie rozważań dotyczących problematyki przedsiębiorczości kobiet, w szczególności determinant, barier i stymulatorów rozwoju.
\end{abstract}

Słowa kluczowe: przedsiębiorczość, przedsiębiorczość kobiet, kobiecy styl zarządzania, równość szans

DOI: 10.17512/znpcz.2016.2.09

\section{Wprowadzenie}

Istotnym elementem zapewniającym rozwój społeczno-gospodarczy jest stworzenie odpowiednich warunków do kreowania postaw przedsiębiorczych na rynku. Podyktowane jest to faktem, iż przedsiębiorczość stanowi okazje do wprowadzania nowych produktów, innowacji, kształtowania nowości rynkowych, a w szczególności do podejmowania ryzyka (Shane, Venkataraman 2000, s. 217-226). W takim odniesieniu przedsiębiorczość odnosi się do sposobu podejmowania działań na rynku przez przedsiębiorców, którzy zdaniem E.P. Lazeara (Lazear 2004, s. 208-211) są jednym z najważniejszych graczy w nowoczesnej gospodarce, przyczyniających się, w opinii J. Hendersona, do tworzenia wzrostu gospodarczego w swoich społecznościach poprzez tworzenie nowych firm (Henderson 2002, s. 45-70). W związku z tym istotnego znaczenia nabiera przedsiębiorca, który kierując się motywem osiągnięcia zysku, zakłada działalność gospodarczą, angażuje swoje zasoby (finansowe, rzeczowe, ludzkie), podejmuje określone decyzje oraz, co istotne, ponosi ryzyko związane z zarządzaniem przedsiębiorstwem.

Z uwagi na fakt, iż przedsiębiorczość jest istotną siłą kształtującą zmiany w gospodarce, badanie czynników, które wpływają na tempo tworzenia nowych firm, stało się ważnym zagadnieniem ekonomistów, naukowców i polityków w większości krajów, w szczególności w odniesieniu do równości płci. Wynika to z faktu, iż prowadzenie własnej działalności gospodarczej w przypadku kobiet i mężczyzn różni się np. sposobem zarządzania, podejmowaniem decyzji czy sty- 
lem kierowania. Jak można zauważyć, liczba kobiet przedsiębiorców, z roku na rok na całym świecie stopniowo wzrasta. Jednakże w dalszym ciągu kobiety mają mniejszą możliwość podejmowania decyzji, współuczestniczenia w zarządzaniu, co jest wynikiem konieczności godzenia aktywności zawodowej z rolami pełnionymi w rodzinie. Jak pokazują statystyki, jedynie $30 \%$ kobiet pracuje na własny rachunek, będąc właścicielami mikro i małych przedsiębiorstw, co prowadzi do niewykorzystania potencjału wzrostu gospodarczego. Potwierdzają to rozważania A. Revenga, S. Sudhir (Revenga, Sudhir 2012, s. 40), według których rozwój społeczno-gospodarczy nie może być osiągnięty bez aktywnego udziału kobiet we wszystkich aspektach życia, dlatego też istotne jest promowanie różności płci w biznesie. W takim odniesieniu należałoby się zastanowić, jakie czynniki wpływają na kreowanie przedsiębiorczości wśród kobiet w biznesie. Celem rozważań jest przedstawienie kobiet na rynku pracy, ze szczególnym uwzględnieniem czynników kreujących przedsiębiorczość kobiet na rynku.

\section{Przedsiębiorcza kobieta w biznesie}

Rosnące znaczenie kobiet na rynku pracy, a głównie w biznesie, jest wynikiem przeobrażeń społeczno-gospodarczych, jakie zaszły w naszym kraju, zmieniając przypisywaną im rolę $\mathrm{w}$ społeczeństwie. $\mathrm{Z}$ tego też względu przedsiębiorczość kobiet stanowi wieloaspektowy obszar badawczy. $Z$ jednej strony jest to ważne wyzwanie współczesnych społeczeństw, a wykorzystanie potencjału przedsiębiorczości tkwiącego w kobietach jest kluczowe dla rozwoju gospodarczego. $Z$ drugiej jednak strony podejmowanie działalności na własny rachunek przez kobiety i wchodzenie w podwójną rolę, jaką pełnią: właścicielek firm, zatem aktywnych zawodowo, jak i matek-opiekunek, jest mocno uwarunkowane kulturowo (Przedsiębiorczość kobiet w Polsce 2011, s. 14). Można zatem stwierdzić, iż kobiety przedsiębiorcze realizują model „kariery zawodowo-rodzinnej”. Jak pisze A. Titkow, realizacja określonych ról życiowych kobiet związana jest $\mathrm{z}$ charakterystykami psychologicznymi (np.: obraz własnej osoby, typ kobiecości, męskości) i socjologicznymi (np.: wiek, miejsce zamieszkania, wykształcenie), co wskazuje głównie na społeczne uwarunkowania planów życiowych kobiet (Titkow 2007, s. 137). Dlatego też kobiety w porównaniu $\mathrm{z}$ mężczyznami postrzegane są w kontekście obowiązków rodzinnych, z mniejszą elastycznością względem pory dnia, jaką mogą poświęcić na pracę, choć panowie także mają rodziny i są rodzicami.

Zdaniem E. Kolasińskiej w polskich przedsiębiorstwach dominują dwa światy, tj. (Kolasińska 2012, s. 24):

- męski, w którym mężczyźni to beneficjenci prestiżowych miejsc pracy i przywilejów;

- kobiecy, gdzie kobiety to „aktorki społeczne”, otrzymujące oferty pracy poniżej swoich kompetencji i ambicji, często dyskryminowane.

Potwierdzeniem powyższego są badania prowadzone przez T. Kupczyk, które

dowiodły, że przedsiębiorcze kobiety (Kupczyk 2009, s. 114-116):

- mają trudniejszy dostęp do stanowisk,

- mniej zarabiają na tych samych stanowiskach niż mężczyźni,

- wolniej awansują. 
Taka dysproporcja wynika w szczególności ze stereotypów w wyborze ścieżki kształcenia, orientacji zawodowej czy braku dostępu do szkoleń. $Z$ tego też względu kobietom aktywnym zawodowo dużo łatwiej jest założyć własną działalność gospodarczą niż zmagać się $\mathrm{z}$ trudnościami $\mathrm{w}$ dążeniu do osiągnięcia stanowisk kierowniczych. Co prawda przedsiębiorstwa, które w swoich zarządach mają kobiety, osiągają przeciętnie lepsze wyniki finansowe niż przedsiębiorstwa niemające kobiet we władzach. Przejawia się to przede wszystkich w takich wskaźnikach, jak (Zachorowska i in. 2014, s. 4):

- wartość marki,

- zwrot z kapitału własnego,

- zwrot ze sprzedaży i zwrot z zainwestowanego kapitału,

- zysk.

Należy w tym miejscu zaznaczyć, iż kobiety, które decydują się na prowadzenie własnej firmy, realizują siebie, zaspokajają własne aspiracje, reprezentują bogatszy styl zarządzania. Takie działania $\mathrm{z}$ ich strony mają na celu przede wszystkim walkę ze stereotypami, walkę, w której dążą do udowadniania swoich umiejętności i zdolności.

\section{Aktywna kobieta - czynniki wpływające na sukces kobiet na rynku}

Rozpoznanie czynników wpływających na przedsiębiorczość kobiet wymaga odpowiedniej wiedzy, jak i zrozumienia związku kobiet-przedsiębiorców z rozwojem gospodarczym. Z tego też względu problematyka uwarunkowań przedsiębiorczości kobiet $\mathrm{w}$ Polsce wpisuje się $\mathrm{w}$ przestrzeń łączącą istniejące i stosunkowo rozległe badania oraz analizy dotyczące $z$ jednej strony barier aktywności ekonomicznej polskich kobiet, z drugiej zaś - barier przedsiębiorczości bez uwzględnienia zróżnicowań między płciami (Kurowska 2013, s. 5).

W literaturze przedmiotu wymienia się szereg czynników - motywatorów kreujących przedsiębiorczość kobiet w biznesie. Syntetyczny zestaw motywów podejmowania działalności gospodarczej przedstawily w swoich rozważaniach S. Gostkowska-Dźwig i M. Mrozik, podając takie czynniki, jak (Gostkowska-Dźwig, Mrozik 2013, s. 115-116):

- dążenie do niezależności,

- chęć osiągania wyższych dochodów,

- niezależność finansowa,

- możliwość rozwoju zawodowego,

- negatywne doświadczenia z pracy najemnej,

- sprzyjające warunki na rynku,

- brak innych możliwości zatrudnienia,

- większe możliwości, jakie daje prowadzenie własnego biznesu,

- większa niezależność działania,

- samodzielność w kierowaniu własnym życiem,

- realizacja osobistych celów,

- możliwość pełniejszego wykorzystania umiejętności,

- osiągnięcie sukcesu zawodowego, 
- czynny udział w procesach społecznych,

- poczucie bycia potrzebnym i ważnym, bo osobiście się coś robi,

- dążenie do samodzielności,

- potrzeba godziwych zarobków,

- wyuczony zawód,

- doświadczenie zdobyte w pracy przed założeniem firmy,

- wrodzona przedsiębiorczość,

- zagrożenie bezrobociem,

- nadarzająca się okazja wzbogacenia.

Powyższe czynniki można pogrupować w cztery grupy uwarunkowań kariery zawodowej kobiet (Rysunek 1), tj.:

- tożsamościowe, związane z ,ja” kobiety,

- istniejące stereotypy dotyczące roli kobiety w społeczeństwie,

- uwarunkowania rodzinne,

- czynniki lokalne - bariery zewnętrzne.

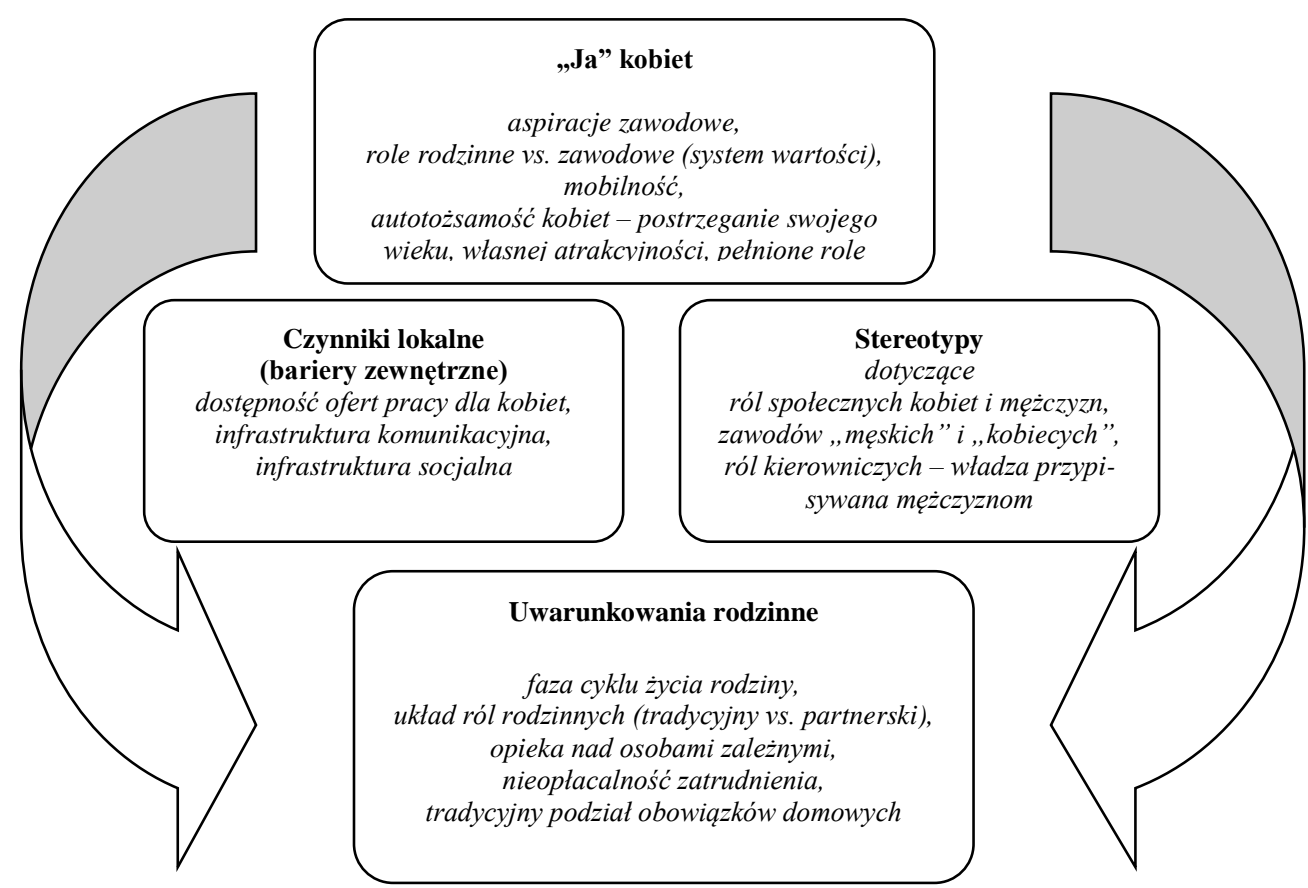

\section{Rysunek 1. Uwarunkowania kariery zawodowej kobiet}

Źródło: (Gładys-Jakóbik 2013, s. 9)

Dokonując rozważań odnoszących się do czynników kreujących przedsiębiorczość kobiet w biznesie, należy zwrócić uwagę, że istnieją pewne faktory, które różnicują poziom aktywności zawodowej wśród kobiet i mężczyzn w poszczególnych krajach. I tak w 2003 roku w ramach programu SCALES (Scientific Analysis of Entrepreneurship and SMEs) holenderscy naukowcy wykazali, iż na wysoki lub 
niski udział kobiet wśród przedsiębiorców w danym kraju wpływają trzy grupy czynników, tj. rozwój technologiczny, czynniki ekonomiczne, czyli PKB i poziom bezrobocia, oraz czynniki kulturowe, zatem wartości i przekonania, które kształtują zachowania przedsiębiorcze. W 2006 roku wyłonili oni dodatkowe grupy czynników wpływających na przedsiębiorczość kobiet, tj.: czynniki społecznodemograficzne oraz czynniki instytucjonalne, a także dowiedli, iż na przedsiębiorczość kobiet wpływają te same czynniki co na przedsiębiorczość mężczyzn, jednakże oddziałują w zróżnicowany sposób (Borowska 2013, s. 155).

Z raportu Przedsiębiorczość kobiet w Polsce, opracowanego w 2011 roku przez PARP (www.badania.parp.gov.pl), wynika, iż jeśli chodzi o czynniki „przyciągające" zarówno kobiety, jak i mężczyzn, to zarówno jedni, jak i drudzy motywowani są do prowadzenia własnego biznesu przez podobne bodźce. Najczęściej wskazywanym czynnikiem do pracy na rachunek własny jest chęć wykorzystania sprzyjających okoliczności (21,5\% wskazań w obu grupach badanych). Szczegółowy rozkład odpowiedzi odnoszący się do czynników wpływających na kreowanie przedsiębiorczości przedstawia Rysunek 2.

Obok przedstawionych czynników kreujących przedsiębiorczość kobiet w biznesie istotną rolę odgrywają cechy osobowościowe, odnoszące się w szczególności do uznania przez przedsiębiorców swoich atutów, dzięki którym przedsiębiorca ma siłę i motywację do dalszego działania.

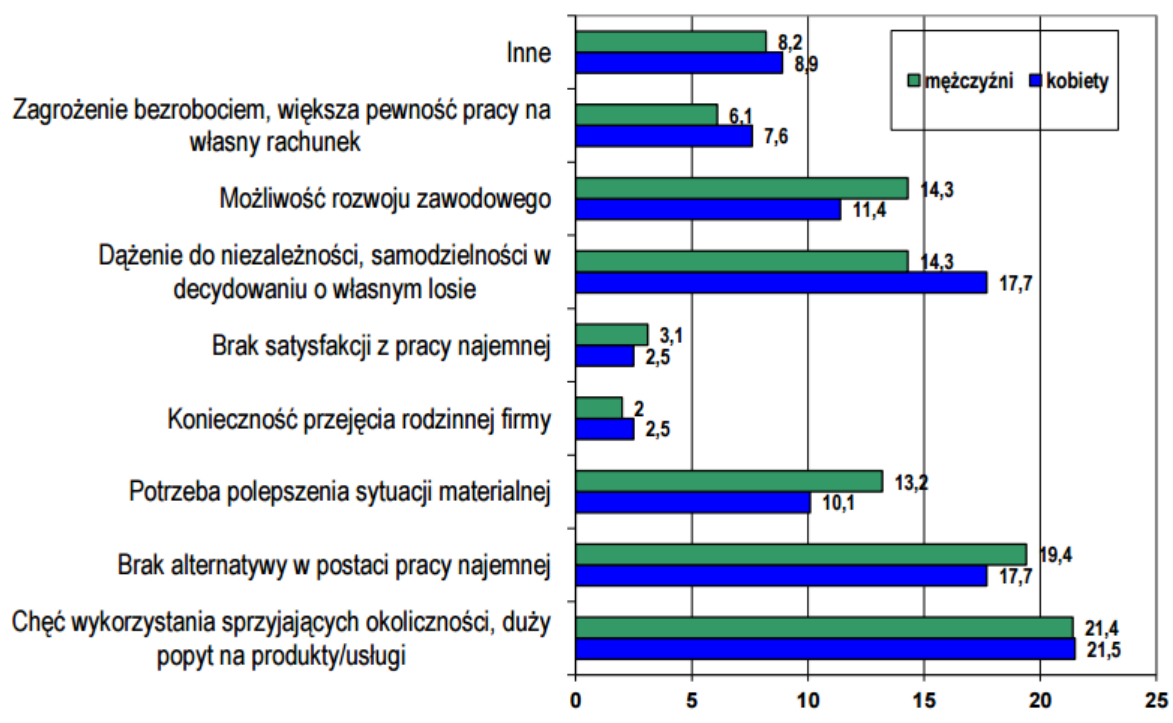

Rysunek 2. Czynniki wpływające na założenie własnej działalności

Źródło: (Przedsiębiorczość kobiet w Polsce 2011, s. 48)

Z tego też względu kobieta, która chce być uznana za kobietę sukcesu - kobietę przedsiębiorczą, powinna odznaczać się przede wszystkim (Godlewska-Majkowska 2009, s. 26): 
- ambicją i pragnieniem wyróżnienia się w sytuacjach konkurencyjnych,

- wytrwałością i determinacją umożliwiającą przezwyciężanie przeszkód i trudności,

- samodzielnością w podejmowaniu decyzji,

- zorientowaniem w działaniu na szanse i okazje,

- zaufaniem do własnych umiejętności kontrolowania zdarzeń,

- kreatywnością i innowacyjnością.

Oczywiście przedstawione powyżej cechy nie wyczerpują listy wszystkich cech, jakie powinien posiadać przedsiębiorca. Co więcej - powyższe cechy odnoszą się do każdego przedsiębiorcy, bez względu na płeć, a właściwa identyfikacja tych przymiotów wpływa na przedsiębiorcze postawy.

\section{Udział kobiet w kreowaniu przedsiębiorczości}

Przeprowadzone dotychczas analizy obrazujące poziom przedsiębiorczości kobiet wskazują na istotne różnice w traktowaniu kobiet i mężczyzn na rynku pracy. Zróżnicowanie ról poszczególnych płci zostały wyodrębnione po analizie poziomu przedsiębiorczości przeprowadzonej przez A. Rubio-Banóna, N. Esteban-Lloret (Rubio-Banóna, Esteban-Lloret 2016, s. 1-9), na podstawie danych GEM (Global Entrepreneurship Monitor) z 2013 roku, z 55 krajów, a także w oparciu o wskaźnik męskości Hofstede, tj. stopień, w jakim dane społeczeństwo przywiązuje i promuje wartości uznawane za męskie (Tabela 1).

Tabela 1. Podstawowe różnice między społeczeństwami kobiecymi i męskimi

\begin{tabular}{|c|c|}
\hline Społeczeństwo kobiece & Społeczeństwo męskie \\
\hline $\begin{array}{l}\text { Polega na narodowym nastawieniu na opieko- } \\
\text { wanie się innymi oraz na troskę o jakość życia }\end{array}$ & $\begin{array}{l}\text { Polega na narodowym nastawieniu na pewność } \\
\text { siebie, zdobywanie pieniędzy i dóbr materialnych }\end{array}$ \\
\hline Ważni są ludzie i przyjazne relacje między nimi & Ważne są pieniądze i dobra materialne \\
\hline Pracuje się, żeby żyć & Żyje się, żeby pracować \\
\hline $\begin{array}{c}\text { Menedżerowie kierują się intuicją i dążą do } \\
\text { porozumienia }\end{array}$ & $\begin{array}{c}\text { Menedżerowie powinni podejmować zdecydowane } \\
\text { decyzje i być asertywni }\end{array}$ \\
\hline $\begin{array}{c}\text { Ważna jest równość, solidarność i jakość życia } \\
\text { zawodowego }\end{array}$ & $\begin{array}{c}\text { Ważna jest sprawiedliwość, współzawodnictwo } \\
\text { pracy i osiągnięcia }\end{array}$ \\
\hline $\begin{array}{c}\text { Konflikty są rozwiązywane na drodze kom- } \\
\text { promisu i negocjacji }\end{array}$ & Konflikty są rozwiązywane przez konfrontację siły \\
\hline
\end{tabular}

Źródło: (Sikora, Wartecka-Ważyńska 2007, s. 24-25) 
Zgodnie z badaniami A. Rubio-Banóna, N. Esteban-Lloret (Rysunek 3), a także po uwzględnieniu wskaźnika męskości Hofstede, Polska, obok takich krajów jak: Indie, Czechy, Grecja, Niemcy, USA, Ekwador, Filipiny, Chiny, Irlandia, Wielka Brytania, Belgia, Kanada, jest krajem o umiarkowanej męskości (indeks Hofstede skali 25-50).

Biorąc z kolei pod uwagę udział kobiet na rynku pracy, prowadzących własną działalność gospodarczą, to osiąga on w Polsce poziom $35,1 \%$, podczas gdy przeciętny udział kobiet wśród samozatrudnionych w UE wynosi 30,6\% (Rysunek 4). Można zatem stwierdzić, iż Polska w porównaniu z innymi krajami Unii ma dużo powodów do zadowolenia w aspekcie przedsiębiorczych kobiet na rynku.

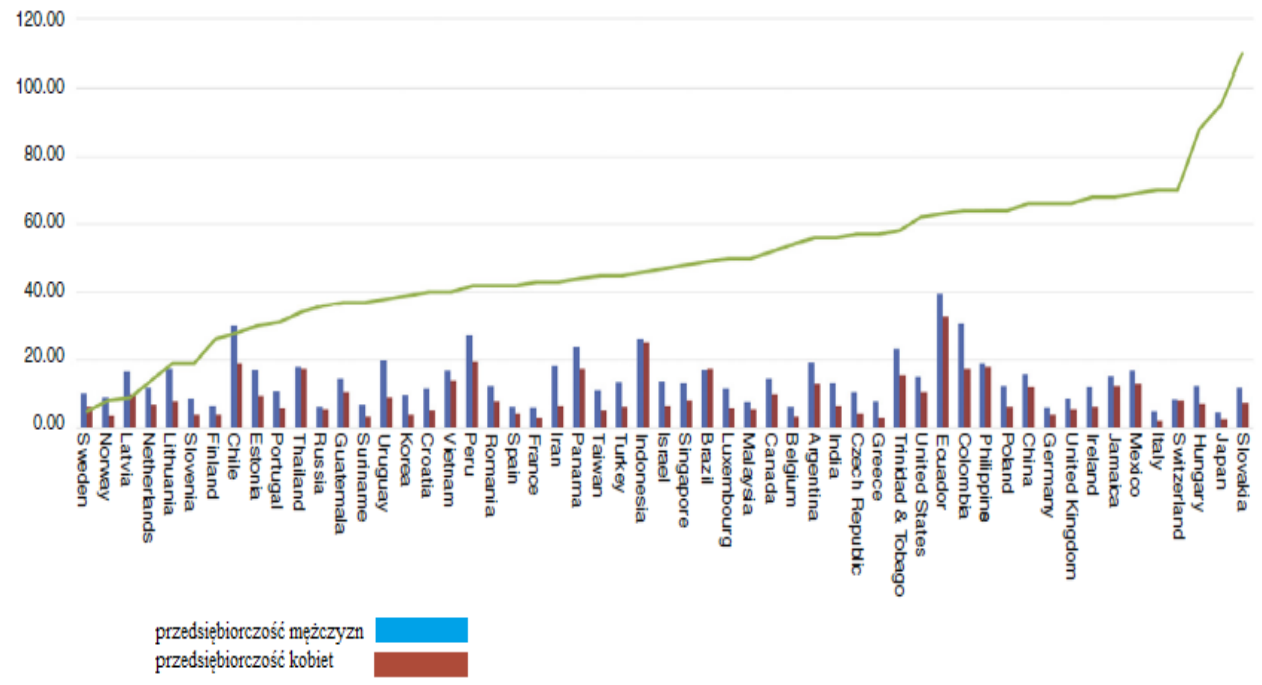

Rysunek 3. Wskaźnik przedsiębiorczości kobiet

Źródło: (Rubio-Banóna, Esteban-Lloret 2016, s. 4)

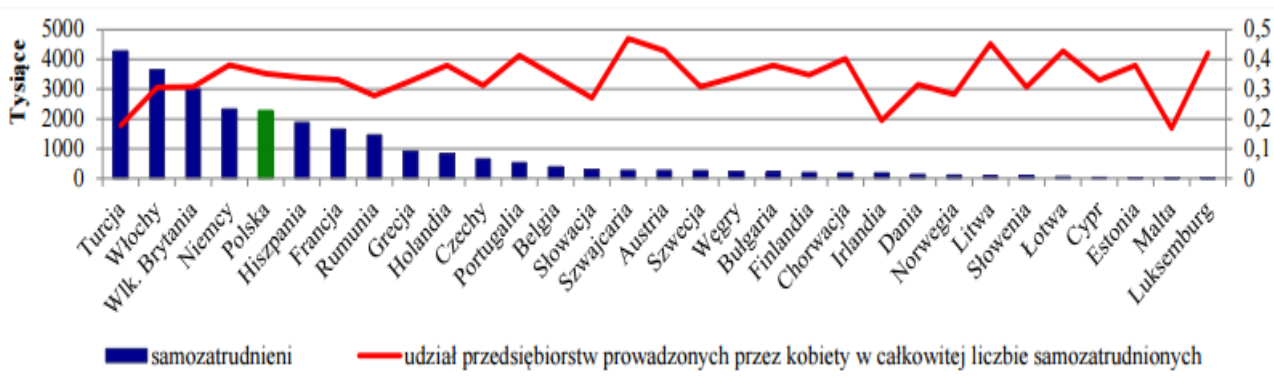

Rysunek 4. Udzial przedsiębiorstw prowadzonych przez kobiety w krajach Unii Europejskiej

Źródło: (https://badania.parp.gov.pl) 
Dokonując bardziej szczegółowej analizy przedsiębiorczości kobiet na rynku w Polsce, należy stwierdzić, iż poziom aktywności zawodowej kobiet jest niższy niż mężczyzn (Rysunek 5).

Z danych przedstawionych przez GUS (Kobiety $i$ mężczyźni na rynku pracy 2014, s. 3-16) wynika, iż w latach 2010-2013 współczynnik aktywności zawodowej kobiet wzrósł $\mathrm{w}$ stosunku do roku bazowego o jeden punkt procentowy i ukształtował się na poziome $48,5 \%$. Biorąc pod uwagę rozkład aktywności zawodowej według wieku, można zauważyć, że w 2013 roku największy odsetek kobiet aktywnych zawodowo wystąpił w przedziale wiekowym 40-44 lata. Z kolei biorąc pod uwagę poziom wykształcenia, daje się zauważyć, że współczynnik aktywności zawodowej dla tej populacji kobiet jest najbardziej zbliżony do wartości analogicznego wskaźnika dla mężczyzn (Rysunek 6). W 2013 roku kobiety najczęściej pracowały w takich sekcjach jak: opieka zdrowotna i pomoc społeczna, a także edukacja, w których kobiety stanowiły ok. 8 na10 pracujących osób.

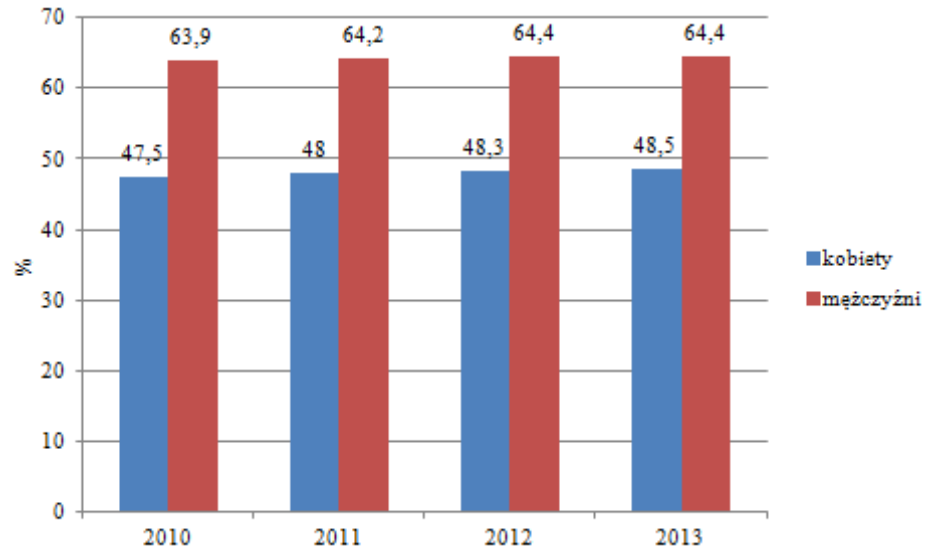

Rysunek 5. Współczynnik aktywności zawodowej ludności według płci w latach 2010-2013

Źródło: Opracowanie własne na podstawie: (Kobiety i mężczyźni na rynku pracy 2014, s. 3)

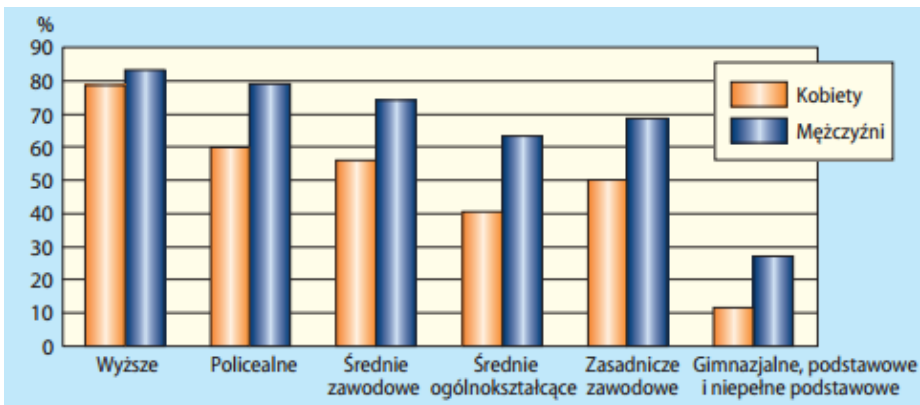

Rysunek 6. Współczynnik aktywności zawodowej według płci i poziomu wykształcenia w 2013 roku

Źródło: (Kobiety i mężczyźni na rynku pracy 2014, s. 5) 


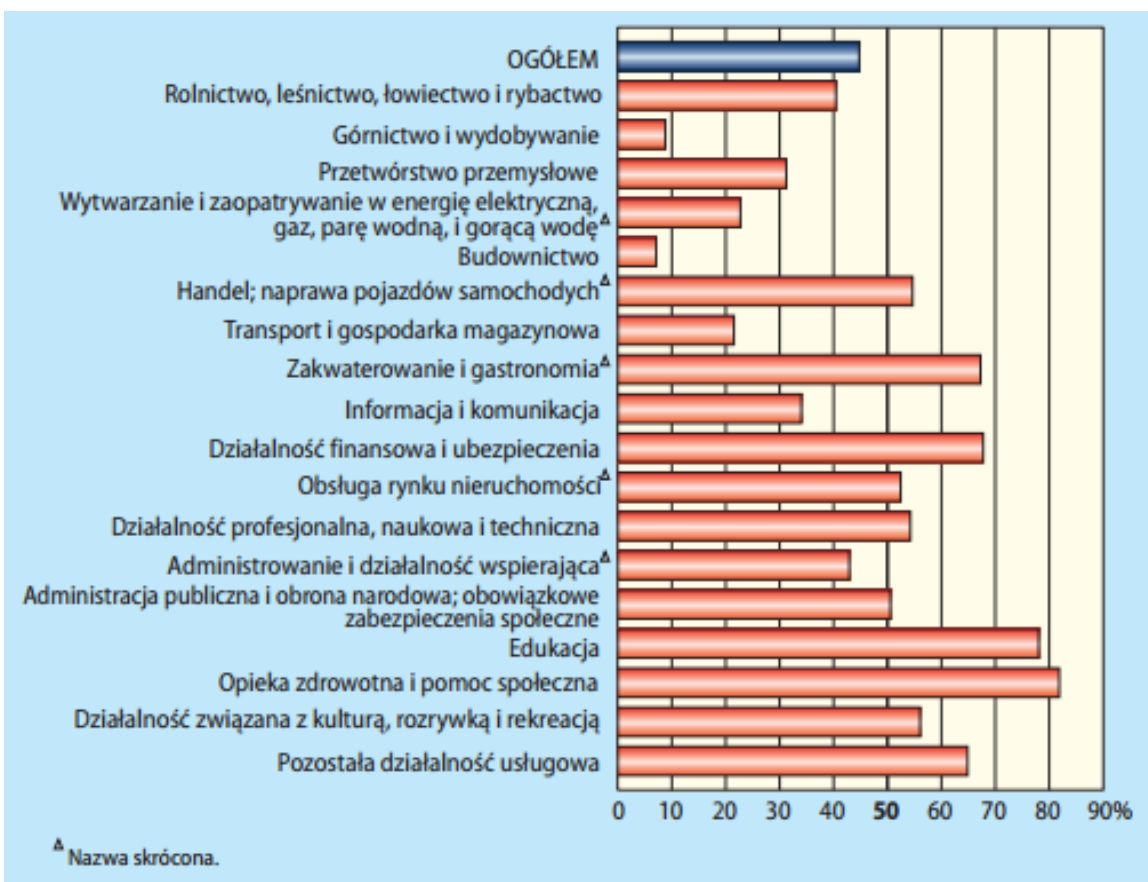

Rysunek 7. Udział kobiet wśród pracujących według wybranych rodzajów działalności / miejsca pracy w 2013 roku

Źródło: (Kobiety i mężczyźni na rynku pracy 2014, s. 8)

Wysoki odsetek zatrudnionych kobiet charakteryzuje też sekcje: zakwaterowanie i gastronomia oraz działalność finansowa i ubezpieczeniowa (190 kobiet na 100 mężczyzn). Natomiast w budownictwie i górnictwie rzadziej niż co dziesiąty pracownik jest kobietą.

\section{Podsumowanie}

Problematyka funkcjonowania przedsiębiorstw zarządzanych przez kobiety jest obecnie coraz częściej podejmowana w naukach o ekonomii czy zarządzaniu. Wynika to $\mathrm{z}$ faktu, iż w Polsce, jak i pozostałych krajach Unii Europejskiej, dużą wagę przykłada się do zachęcania kobiet do podejmowania przez nie działalności gospodarczej.

Pomimo rosnącej liczby kobiet-przedsiębiorców, udział kobiet jest nadal znacznie niższy w porównaniu z przedsiębiorczością wśród mężczyzn. Podyktowane jest to $\mathrm{w}$ głównej mierze szeregiem barier związanych z godzeniem obowiązków zawodowych z rodzinnymi, a także stereotypami, jakie panują w społeczeństwie. Dużą rolę w przezwyciężeniu barier, a jednocześnie we wspieraniu aktywności biznesowej kobiet odgrywają instytucje pozarządowe, a także szereg inicjatyw mających na celu pobudzanie i kreowanie przedsiębiorczości wśród kobiet. 


\section{Literatura}

1. Borowska A. (2013), Determinanty i bariery przedsiębiorczości kobiet w Polsce, „Economics and Management", $\mathrm{nr} 3$.

2. Gładys-Jakóbik J. (2013), W poszukiwaniu wzorów tożsamości polskich kobiet, „Kobieta i Biznes", nr 1-4.

3. Godlewska-Majkowska H. (red.) (2009), Przedsiębiorczość. Jak założyć i prowadzić własną firmę?, Oficyna Wydawnicza SGH, Warszawa.

4. Gostkowska-Dźwig S., Mrozik M. (2013), Kreatywność i potencjał kobiet w zakresie przedsiębiorczej postawy - wybrane problemy, [w:] Skowron-Grabowska B. (red.), Rozwój przedsiębiorczości, Sekcja Wydawnictw Wydziału Zarządzania Politechniki Częstochowskiej, Częstochowa.

5. Henderson J. (2002), Building the Rural Economy with High-Growth Entrepreneurs, Federal Reserve Bank Kansas City, Kansas City.

6. https://badania.parp.gov.pl (dostęp: 15.03.2016).

7. Kobiety i mężczyźni na rynku pracy (2014), GUS, Warszawa.

8. Kolasińska E. (2012), Deprecjacja kompetencji kobiet w polskich organizacjach, „Kobieta i Biznes", nr 1-4.

9. Kupczyk T. (2009), Kobiety w zarządzaniu i czynniki ich sukcesów, Wyższa Szkoła Handlowa, Wrocław.

10. Kurowska A. (2013), Uwarunkowania przedsiębiorczości kobiet w Polsce związane z macierzyństwem, „Kobieta i Biznes”, nr 1-4.

11. Lazear E.P. (2004), Balanced Skills and Entrepreneurship, "American Economic Review”, Vol. 94(2), s. 208-211.

12. Przedsiębiorczość kobiet w Polsce (2011), PARP, Warszawa.

13. Revenga A., Sudhir S. (2012), Empowering Women is Smart Economics, "Finance \& Development", March 2012/49(1).

14. Rubio-Banóna A., Esteban-Lloret N. (2016), Cultural Factors and Gender Role in Female Entrepreneurship, "Suma de Negocios", Vol. 7, Issue 15.

15. Shane S., Venkataraman S. (2000), The Promise of Entrepreneurship as a Field of Research, "Journal of Management", Vol. 25(1), s. 217-226.

16. Sikora J., Wartecka-Ważyńska A. (2007), Możliwości zastosowania modelu kultury organizacyjnej G. Hofstede w badaniach nad zarządzaniem przedsiębiorstwem w Polsce, [w:] Banaszak S., Doktór K. (red.), Socjologiczne i psychologiczne problemy organizacji i zarządzania, Wydawnictwo Wyższej Szkoły Komunikacji i Zarządzania, Poznań.

17. Titkow A. (2007), Tożsamość polskich kobiet. Ciągłość, zmiana, konteksty, IFiS PAN, Warszawa.

18. www.badania.parp.gov.pl

19. Zachorowska M., Sznajder A., Lisowska E., Grabowska M. (2014), Więcej kobiet w zarządzaniu - to się opłaca. Przewodnik dla firm, Ministerstwo Pracy i Polityki Społecznej, Warszawa. 


\title{
FACTORS CREATING THE ENTREPRENEURSHIP OF WOMEN IN BUSINESS
}

\begin{abstract}
At a recent time, observes the increasing role of women in the creation of entrepreneurship. For this reason, more often it is recognized the importance of a diversity policy relating to the issue of women in management positions and, above all, creating entrepreneurial attitudes. Unfortunately, women still in an unequal degree participate in corporate management, decision-making or in the implementation of the objectives of the organization. This is due to the fact that towards women are made higher demands (qualification, organizational, managerial) than men. In this point of view, it is reasonable to take consideration of the issue of women's entrepreneurship, in particular determinants, barriers and drivers of development.
\end{abstract}

Keywords: entrepreneurship, women's entrepreneurship, feminine style of management, equal opportunities 